\title{
THE IMPROVEMENT OF RAMIE FIBER PROPERTIES AS COMPOSITE MATERIALS USING ALKALIZATION TREATMENT: NaOH CONCENTRATION
}

\author{
U. L. Jamilah and Sujito \\ Laboratorium of Material Physics, Department of Physics, Faculty of Mathematics and Natural \\ Sciences, University of Jember, Jl. Kalimantan 37, Jember 68121, Indonesia \\ E-mail: umilailatul442@gmail.com
}

Received: 15 January 2021

Revised: 14 April 2021

Accepted: 21 April 2021

\begin{abstract}
THE IMPROVEMENT OF RAMIE FIBER PROPERTIES AS COMPOSITE MATERIALS USING ALKALIZATION TREATMENT: NaOH CONCENTRATION. Ramie fiber is a plant fiber that has good quality and potential as a constituent of composite materials. In this study, ramie fiber surface modification was conducted through alkalization with various at $0 \%, 4 \%, 5 \%, 6 \%, 7 \%, 8 \%$, and $9 \%$ concentrations of $\mathrm{NaOH}$ using a magnetic stirrer with a speed of $200 \mathrm{rpm}$ at $70^{\circ} \mathrm{C}$ for 5 hours. Alkaline ramie fibers are characterized using the Cheson method to determine the chemical composition of ramie fiber, FT-IR test to determine the function group of ramie fiber, morphological test to know the surface structure and diameter of ramie fiber, as well as tensile test to know the tensile strength and tensile modulus of PLA/ramie composite. Overall, the increase of $\mathrm{NaOH}$ concentration up to $8 \%$ percentage was able to increase the level of cellulose and lignin ramie fibers by $88.180 \%$ and $2.444 \%$, as well as lower hemicellulose levels of $1.446 \%$. The alkalization treatment of $8 \% \mathrm{NaOH}$, optimally reduces the hydrophilic properties of the fiber. The increased concentration of $\mathrm{NaOH}$ makes the fiber surface cleaner and the diameter smaller, but the fiber structure is damaged at a concentration of $\mathrm{NaOH}$ more than $8 \%$. Tensile test results showed that alkalized ramie fibers with an $8 \%$ concentration of $\mathrm{NaOH}$ produced PLA/ramie composites with the highest tensile strength and tensile modulus of $57.37 \mathrm{MPa}$ and $248.25 \mathrm{MPa}$. Thus, the optimum ramie fiber properties are increased using alkalization with an $8 \%$ concentration of $\mathrm{NaOH}$.
\end{abstract}

Keywords: Composite Material, Alkalization, Properties of Ramie Fiber

\begin{abstract}
ABSTRAK
PENINGKATAN PROPERTIS SERAT RAMI SEBAGAI PENYUSUN MATERIAL KOMPOSIT MELALUI PERLAKUAN KIMIA ALKALISASI: KONSENTRASI NaOH. Serat rami merupakan serat tumbuhan yang memiliki kualitas baik dan berpotensi sebagai penyusun material komposit. Pada penelitian ini dilakukan modifikasi permukaan serat rami melalui perlakuan kimia alkalisasi dengan variasi konsentrasi $\mathrm{NaOH}$ $0 \%, 4 \%, 5 \%, 6 \%, 7 \%, 8 \%$ dan $9 \%$ menggunakan magnetic stirrer dengan kecepatan $200 \mathrm{rpm}$ pada suhu $70^{\circ} \mathrm{C}$ selama $5 \mathrm{jam}$. Serat rami hasil alkalisasi dikarakterisasi menggunakan metode Cheson untuk mengetahui komposisi kimia serat rami, uji FT-IR untuk mengetahui gugus fungsi serat rami, uji morfologi untuk mengetahui struktur permukaan dan diameter serat rami, serta uji tarik untuk mengetahui kuat tarik dan modulus tarik komposit PLA/rami. Secara keseluruhan peningkatan konsentrasi $\mathrm{NaOH}$ hingga persentase $8 \%$ mampu meningkatkan kadar selulosa dan lignin serat rami yaitu $88,180 \%$ dan $2,444 \%$, serta menurunkan kadar hemiselulosa yaitu 1,446\%. Perlakuan alkalisasi $\mathrm{NaOH} 8 \%$, optimum menurunkan sifat hidrofilik pada serat. Peningkatan konsentrasi $\mathrm{NaOH}$ membuat permukaan serat semakin bersih dan diameternya semakin kecil, namun struktur serat mengalami
\end{abstract}


kerusakan pada konsentrasi $\mathrm{NaOH}$ lebih dari $8 \%$. Hasil uji tarik menunjukkan serat rami hasil alkalisasi dengan konsentrasi $\mathrm{NaOH} 8 \%$ menghasilkan komposit PLA/rami dengan kuat tarik dan modulus tarik tertinggi yaitu 57,37 MPa dan 248,25 MPa. Dengan demikian, propertis serat rami optimum ditingkatkan menggunakan metode alkalisasi pada konsentrasi $\mathrm{NaOH} 8 \%$.

Kata kunci: Material Komposit, Alkalisasi, Sifat Serat Rami

\section{INTRODUCTION}

The form of care for the environment can be demonstrated by the use of environmentally friendly materials in daily life. Green composite material is an environmentally friendly composite material consisting of biodegradable polymers as a matrix and natural fibers as reinforcement [1]. Natural fiber-based composite materials have received great attention due to their lightweight, non-destructive, non-toxic, low cost, and biodegradable properties [2]. Natural fibers that are often used and have good potential to be used as reinforcement composite materials is ramie fiber.

Ramie fiber is a plant fiber extracted from the stems of ramie plants. Ramie fiber has become one of the oldest natural vegetable fibers, used for thousands of years for fabric and clothing [3]. Apart from the use of textile, ramie fiber can be utilized to produce a wide range of products [4]. Ramie fiber is one of the natural fibers with better mechanical properties [5]. Ramie fiber is also one of the strongest natural fibers that have a lot of cellulose content. Cellulose is a polysaccharide that can be expressed by a simple chemical formula $\left(\mathrm{C}_{6} \mathrm{H}_{10} \mathrm{O}_{5}\right)_{\mathrm{n}}$. The chemical composition of ramie fiber is shown in Table 1 [4].

Table 1. Chemical composition of bast fibers [4].

\begin{tabular}{cccccc}
\hline Fiber & Cellulose & Hemicellulose & Pectin & Lignin & Fat \\
\hline Flax & $64-84$ & $16-18$ & $1.8-2.0$ & $0.6-0.5$ & 1.5 \\
Hemp & $67-78$ & $16-18$ & 0.8 & $3.5-5.5$ & 0.7 \\
Ramie & $67-99$ & $13-14$ & $1.9-2.1$ & $0.5-1.0$ & 0.3 \\
Jute & $51-78$ & $12-13$ & $0.2-4.4$ & $10-15$ & 0.5 \\
\hline
\end{tabular}

From Table 1, it can be observed that the cellulose content in ramie fiber is more than other bast fibers such as Jute and Hemp. The mechanical properties of plant fibers, largely depend on the amount of cellulose [4]. Thus, ramie fiber has good potential to be used as a reinforcement of green composite material.

The characteristics of composite materials don't just depend on the physical and mechanical properties of the natural fiber used. Several factors also affect the characteristics of the composite materials, including interfacial bonding between the reinforcement and matrix, the large surface area of the reinforcement, dimensions, and direction of the reinforcement, modifications of the reinforcement surface, the fraction of the volume of the reinforcement, and others [6]. The fiber interface and matrix have a very important function which is to transfer the load from the matrix to the fiber. This interface is influenced by fiber binding processes and matrix that depend on the adhesion strength between fiber and matrix. Fiber surface treatment is an important factor in determining the properties and adhesion levels produced by fiber and matrix [7]. Fiber adhesion and matrix level are also influenced by the hydrophilic properties of natural fibers. Hydrophilic properties cause low adhesion bonds between natural fiber and hydrophobic matrix [8]. Hydrophilic properties in fibers are mostly caused by hemicellulose and cellulose levels [9]. Cellulose levels are an important component in determining the mechanical properties of fiber, so lowering the hydrophilic properties of the fiber can be done by eliminating hemicellulose components in the fiber. Besides, the bond between fiber and matrix will become stronger by removing wax coating on fiber such as lignin and other impurities [9]. Thus, it is necessary to modify the fiber surface that can degrade the hydrophilic properties of natural fiber and eliminate other components that are not needed in fibers such as lignin. Thus, the fiber will have good physic and mechanical properties, in addition to having adhesion strength and a large with matrix.

Fiber modification can be done using chemicals, enzymes, and heat treatment. Chemical modification can be differentiated as alkalization, acetylation, coupling agents, permanganate, and others [10]. Alkalization is one of the effective ways of modifications on the fiber surface. It can improve mechanical properties, make a rough surface on fibers, and increasing the amount of amorphous cellulose [2]. Modification of fiber surface using Alkalization can decrease hydrophilic properties in natural fibers and increase the resistance of natural fibers to water. Thus, the interaction between natural fiber and matrix can be improved [11]. 
Some studies on the surface modification of ramie fibers using alkaline methods have been conducted. Including, research of Debeli et al. [12], aims to know the best results of the modification of the surface of ramie fibers when using alkaline, silane, and the combination of alkaline with silane. The results showed that the resulting composite material had better mechanical properties of the fibers that are given alkaline treatment using $\mathrm{NaOH} 7 \%$ ( $7 \mathrm{~g} / 100 \mathrm{ml}$ water) for 3 hours at room temperature than silane treatment and the combination of alkaline with silane. Further research conducted by Syafri et al. [13], aims to know the influence of variations in the concentration of $\mathrm{NaOH}$ adapted to the properties of ramie fiber. The study was conducted by soaking ramie fiber in $\mathrm{NaOH}$ solution with various concentrations of $\mathrm{NaOH}$ at $0 ; 2.5 ; 5 ; 7.5 \%$ at temperature $100{ }^{\circ} \mathrm{C}$ for 4 hours. The results showed that cellulose level in ramie fiber and tensile strength of ramie fiber tend to decrease with the increased level of $\mathrm{NaOH}$ used. This is due to the degradation of lignin, hemicellulose, and also cellulose. It is also suspected that due to the influence of temperatures that are too high, it damages the structure of the fiber. Then, research conducted by Kusmono et al. [14], aims to modify the surface of ramie fibers using several chemical treatments at once, namely de-waxing, bleaching, and alkalizing to improve the properties of ramie fibers. The de-waxing process is carried out by soaking the ramie fiber into the toluene-ethanol solution, followed by bleaching using a solution of $0.7 \%$ sodium chloride $\left(\mathrm{NaClO}_{2}\right)$ at a temperature of $75^{\circ} \mathrm{C}$ for 1 hour. Lastly, the fiber is given an alkaline treatment by soaking fiber in a solution of $2 \% \mathrm{NaOH}$ for 2 hours. The results showed that the chemical treatment of de-waxing, bleaching, and also alkalization was able to eliminate lignin and hemicellulose components in ramie fibers, increasing crystalline index, and thermal stability in ramie fiber. However, this research is considered less efficient to do, because it uses a variety of chemicals and some processes that must be carried out. Thus, it is necessary to do other ways to modify ramie fiber using the alkaline method but efficiently and effectively.

Based on some of the research above, the modification of the surface of ramie fiber with the alkalization method is a method that can stand on its own in producing good ramie properties. The use of temperature during alkalization should be observed so that unwanted fiber chemical components such as lignin and hemicellulose can be degraded, but not damaging the cellulose structure itself. Excessive use of chemicals and several chemical treatments performed at once can potentially damage the structure of cellulose, so this should be avoided, in addition, to be an effort to maintain environmental sustainability from excessive use of chemicals. For that reason, this study was done by modifying the surface of ramie fiber using the alkalization method to improve the properties of ramie fiber as reinforcement of composite material, to produce good interfacial bonding and large levels of fiber adhesion and matrix. However, in contrast to previous research, in this study, the alkalization process was conducted under the influence of not very high temperatures and mechanical influences using a magnetic stirrer, so it is expected that the alkaline process takes place faster, it would also be more effective and efficient in eliminating lignin and hemicellulose in fibers, lowering fiber diameter and hydrophilic properties in fibers and increasing cellulose levels in fibers.

The research was conducted by varying the concentration of $\mathrm{NaOH}$ used during alkalization. This is done to know the exact concentration value in producing the best ramie fiber properties. From this research, the effects of various $\mathrm{NaOH}$ concentrations on the properties of ramie fiber will be known through modification on the fiber surface using alkalization. The observed properties of ramie fiber include the chemical composition of ramie fibers such as cellulose, hemicellulose, and lignin, then the function group on ramie fiber and the surface morphology of ramie fiber as well as the largest adhesion bond between fiber and matrix indicated by the tensile properties between ramie fiber and PLA matrix. This research is expected to provide information on the improvement of the properties of ramie fiber by using a simple, effective, efficient, and inexpensive alkalization method, which can produce a good composite material constituent to improve the characteristics of composite materials.

\section{EXPERIMENTAL METHOD}

\section{Place and Time of Research}

This research was conducted in the Laboratory of Material Physics, Department of Physics, Faculty of Mathematics and Natural Sciences (MIPA) University of Jember from January to April 2020.

\section{Materials and Instruments}

The instruments used in this study are Hung Ta type HT-2402-10 kN brand tensile testing machine, Metkon IMM 902 brand electron microscope, Thermo 
Scientific Nicolet iS10 brand FT-IR test tool, blender, cold-pressed machine, oven, scissors, trundle, digital balance scale, beaker glass, PH meter, and magnetic stirrer. Meanwhile, the materials used in this study were ramie fiber, PLA pellet type, $\mathrm{NaOH}$, water, aluminum foil, distilled at the water filter paper, $\mathrm{H}_{2} \mathrm{SO}_{4}$, and acetic acid. The ramie fiber used was obtained from BALITTAS (Research Center for Sweeteners and Fiber Plants) Wonosobo, Indonesia.

\section{Ramie Fiber Alkalization and Synthesis of PLA/ramie Composite Materials}

The alkalization method of ramie fiber will be applied in this research. The ramie fiber used is cut to a size of 2-3 $\mathrm{mm}$, then immersed in an alkaline solution with $\mathrm{NaOH}$ concentration variations of $0 \%, 4 \%, 5 \%, 6 \%$, $7 \%, 8 \%$, and $9 \%$ using a magnetic stirrer with a speed of $200 \mathrm{rpm}$ at temperature $70^{\circ} \mathrm{C}$ for 5 hours. The alkalized fibers were washed with a few drops of acetic acid until neutral, then dried in the sun followed by the oven at $100{ }^{\circ} \mathrm{C}$ for $2 \times 15$ minutes. The dried ramie fibers are then blended until they break down into one another and are ready to be characterized. In the tensile test, the PLA/ ramie composite test sample was used, to determine the ability of the ramie fiber to withstand tensile loads and the compatibility of the fiber bonds with the PLA matrix. PLA/ramie composites were synthesized by combining the PLA matrix and ramie fibers with a mass fraction of 95\% PLA: $5 \%$ ramie with a total mass of 80 grams. After the PLA/ramie composite has been synthesized, it is then cut according to testing requirements.

\section{Chemical Composition Testing of Ramie Fibers}

The test of the chemical composition of alkalized ramie fiber was carried out to determine the level of cellulose, hemicellulose, and lignin decomposed using the Cheson method, as follows.

a. First, the sample used 1-2 grams in mass, then pour it into $150 \mathrm{ml}$ of distilled water and heated at $100^{\circ} \mathrm{C}$ for 2 hours, then filtered with filter paper and rinsed with $\mathrm{H}_{2} \mathrm{O}$, then the solid part was dried at $105^{\mathrm{i}} \mathrm{C}$ and weighed, to obtain the dry sample (a). Then the sample was added to $150 \mathrm{ml}$ of $1 \mathrm{~N} \mathrm{H}_{2} \mathrm{SO}_{4}$, and heated at $100{ }^{\circ} \mathrm{C}$ for 1 hour, then filtered with filter paper, and rinsed with distilled water. Furthermore, the solid part was dried at $105^{\circ} \mathrm{C}$ and weighed to obtain a dry sample (b). Then, the hemicellulose level is determined by Equation 1.

Hemicellulose levels $=\frac{\mathrm{a}-\mathrm{b}}{\text { initial weight }} \times 100 \%$

b. Second, to determine the level of cellulose, it was carried out by adding dry sample (b) to $72 \% \mathrm{H}_{2} \mathrm{SO}_{4}$ about $10 \mathrm{ml}$, then immerse it for 4 hours, after which about $150 \mathrm{ml}^{\circ} \mathrm{H}_{2} \mathrm{SO}_{4} 1 \mathrm{~N}$ was added and heated at $100{ }^{\circ} \mathrm{C}$ for 2 hours, then filtered with filter paper, and rinse it with distilled water, then dried in an oven at a temperature of $105^{\circ} \mathrm{C}$, to obtain a dry sample (c). Then, the cellulose content is determined by Equation 2.

Cellulose levels $=\frac{\mathrm{b}-\mathrm{c}}{\text { initial weight }} \times 100 \%$

c. Finally, to determine the lignin level, heat the dry sample (c) at a temperature of $600^{\mathrm{i}} \mathrm{C}$ for about 4-6 hours then weigh it and obtaining ash $(\mathrm{d})$. then, the lignin level is determined by Equation 3.

Lignin levels $-\frac{\mathrm{c}-\mathrm{d}}{\text { initial weight }} \times 100 \%$

\section{Characterization of Ramie Fiber FT-IR}

The characterization of FT-IR (Fourier Transform Infra-Red) is used to identify the function group of a compound based on the intensity of absorption produced. When the frequency of light passed is absorbed by the identified compound, it is transferred to the compound. The amount of energy absorbed by the compound will affect the molecular condition of the compound. The amount of energy required varies with each bond so that each bond will absorb at different frequencies in infrared radiation. The number of frequencies passing through the compound (which is not absorbed) will be measured as a percent transmittance [15]. The characterization of FT-IR in this study used ramie fiber samples without alkalization treatment at $0 \%$ concentrations of $\mathrm{NaOH}$ and with alkaline treatment at $7 \%$ and $9 \%$ concentrations of $\mathrm{NaOH}$. The purpose of this characterization is to determine the effect of alkaline treatment on the functional group contained in ramie fiber.

\section{Ramie Fiber Surface Morphology Test}

Morphology test of ramie fiber surface in this study using electron microscope brand Metkon eIMM 
902. Testing was conducted by placing several alkaline ramie fibers with variations in $\mathrm{NaOH}$ concentration on the table of microscope objects. Then, determined the magnification used, in this study using a magnification of $50 \mathrm{x}$, subsequently, the structure and diameter of ramie fiber were observed. The footage of the observation of ramie fiber is presented in the form of a 2-dimensional by the magnification of the microscope used, then from some of those diameters, we can take the average size to find out the actual diameter of ramie fiber.

\section{Characterization of PLA/ramie Composite Tensile Properties}

Characterizations of PLA/ramie composite tensile properties are done to determine the ability of fiber in forming bonds with PLA matrix when given alkaline treatment with various concentrations of $\mathrm{NaOH}$. In characterizations used as many as 3 samples of each variation in the concentration of $\mathrm{NaOH}$ on the alkalization of ramie fiber. Before testing, the cross-sectional area of the tensile test sample is predetermined as input data on the computer connected to the tensile testing machine. During tensile testing, the tensile test sample is mounted in a tensile testing machine and is given a static load that increases slowly until it breaks. Data obtained from tensile testing in the form of stress $(\sigma)$ and strain $(\varepsilon)$. The data is then converted into a stress and strain graph, to be analyzed for the mechanical properties of tensile strength and tensile modulus.

\section{RESULTS AND DISCUSSION}

\section{Chemical Composition of Ramie Fiber}

Analysis of the chemical composition of ramie fiber in this study was conducted using the Cheson method to determine the level of cellulose, hemicellulose, and lignin in ramie fiber, so that it is known the influence of alkaline chemical treatment on the chemical composition of ramie fiber produced. This analysis is important because the chemical composition of fibers affects the properties of the fiber itself. According to Jose et al. [4], the mechanical properties of plant fibers largely depend on the amount of cellulose in that fiber. This indicates that the higher the cellulose level in the fiber makes the fiber's mechanical properties better. However, high cellulose levels in fiber do not guarantee that they will produce good composite material characteristics. This is due to several other factors that can affect the characteristics of the material. Thus it is necessary to conduct other tests to find out the best properties of fiber capable of producing good composite material characteristics. Meanwhile, the results obtained from testing the chemical composition of ramie fiber in this study were shown in Table 2.

Table 2. Effects on various concentration of $\mathrm{NaOH}$ on the chemical composition of ramie fiber

\begin{tabular}{cccc}
\hline \multirow{2}{*}{$\begin{array}{c}\text { concentration of } \\
\mathrm{NaOH}(\%)\end{array}$} & \multicolumn{3}{c}{ Ramie fiber chemical composition (\%) } \\
\cline { 2 - 4 } & Cellulose & Hemicellulose & Lignin \\
\hline 0 & 83,475 & 4,493 & 1,198 \\
4 & 85,779 & 2,645 & 1,198 \\
5 & 86,098 & 1,545 & 2,093 \\
6 & 80,430 & 5,806 & 4,119 \\
7 & 88,643 & 1,296 & 2,004 \\
8 & 88,180 & 1,446 & 2,444 \\
9 & 79,941 & 4,269 & 6,048 \\
\hline
\end{tabular}

Table 2, shows the influence of various $\mathrm{NaOH}$ concentrations on the chemical composition of ramie fiber produced in the alkalization process. Ramie fiber that is not given alkaline treatment (at $0 \%$ concentration of $\mathrm{NaOH}$ ) has a high cellulose content of $83.475 \%$. This corresponds to the cellulose level of ramie fiber reported by Jose et al. [4] is about $67-99 \%$. Then, as the concentration of $\mathrm{NaOH}$ is increased, the cellulose content of the resulting ramie fiber tends to increase at up to $5 \%$ concentration of $\mathrm{NaOH}$ and decrease at $6 \%$ concentration of $\mathrm{NaOH}$ then at $7 \%$ concentration of $\mathrm{NaOH}$ the resulting cellulose level increases again. The difference in cellulose level is thought to be influenced by the condition of water content at the time of testing, where ramie plants grow related to the content of nutrients and nutrients is the one forming the cellulose [13]. At $8 \%$ concentration of $\mathrm{NaOH}$, cellulose level produced slightly decreased from $7 \%$ of $\mathrm{NaOH}$ but still higher than cellulose level without alkaline treatment, which is $88.180 \%$. The lowest ramie fiber cellulose content was produced at a $9 \%$ concentration of $\mathrm{NaOH}$, which is $79.941 \%$. This value is lower when compared to the cellulose content of ramie fiber without alkaline treatment of $83.475 \%$. Increased concentrations of $\mathrm{NaOH}$ in the alkaline process of ramie fiber cause degradation of the chemical components of cellulose, hemicellulose, and lignin, but excessive concentrations of $\mathrm{NaOH}$ can cause damage to the molecular structure of cellulose, thus lowering cellulose level. Therefore, variations of $\mathrm{NaOH}$ concentration in the alkalization process are important to know to determine if the exact concentration of $\mathrm{NaOH}$ in producing optimum cellulose level, in this study obtained the highest cellulose levels at $7 \%$ concentration of $\mathrm{NaOH}$ which is $88.643 \%$. 
In addition to cellulose level, this study also determined hemicellulose and lignin level in ramie fiber as shown in Table 2. The resulting hemicellulose level tends to decrease with the increased concentration of $\mathrm{NaOH}$ used except at a concentration of $\mathrm{NaOH} 6 \%$, which is due to the differences in the content of lignocellulose in the ramie fiber. The content of lignocellulose is influenced by the place of growth [9]. Meanwhile, the resulting lignin level tends to increase with the increasing concentration of $\mathrm{NaOH}$ used. Thus, overall it can be concluded that increasing the concentration of $\mathrm{NaOH}$ in the alkaline process can increase cellulose and lignin levels as well as lower hemicellulose levels. The results of this study are following the results of research that has been reported by Syahri et al. [13], in which $\mathrm{NaOH}$ treatment causes the degradation of lignin, hemicellulose, and also cellulose in fiber. With this degradation, the chemical composition of the fiber will decompose, where lignocellulose reacts with $\mathrm{NaOH}$ resulting in cellulose and lignin that are still bonded with hemicellulose. Meanwhile, the decreasing level of hemicellulose is due to its relatively much more sensitive nature to alkaline reactions than cellulose and lignin, so that the content of hemicellulose in fiber easily dissolves during the alkalization process [16]. These results are also supported by the results of Kondo and Arsyad's research [9], in which overall alkaline treatment will decrease the content of hemicellulose, increasing the level of cellulose and lignin.

\section{Ramie Fiber FT-IR Spectrum}

FT-IR spectrum analysis of ramie fibers is used to determine the influence of various $\mathrm{NaOH}$ concentrations on the ramie fiber function group. The analysis of the function group was conducted using samples of ramie fiber without alkaline treatment $(0 \%$ of $\mathrm{NaOH}$ ), and alkaline treatment at $7 \%, 8 \%$ and $9 \%$ concentration of $\mathrm{NaOH}$. The results obtained from FTIR testing, in this study are shown in Figure 1.

Figure 1 is the FT-IR spectrum of alkaline ramie fiber using $\mathrm{NaOH}$ concentrations of $0 \%, 7 \%, 8 \%$, and $9 \%$. The FT-IR test results are then qualitatively analyzed to determine the functional group contained in alkaline ramie fiber. The number of waves in Figure 1 indicates the presence of a compound function group in ramie fiber, while the transmittance indicates the amount of energy frequency passing through the compound. The higher the transmittance peak, the greater the energy is

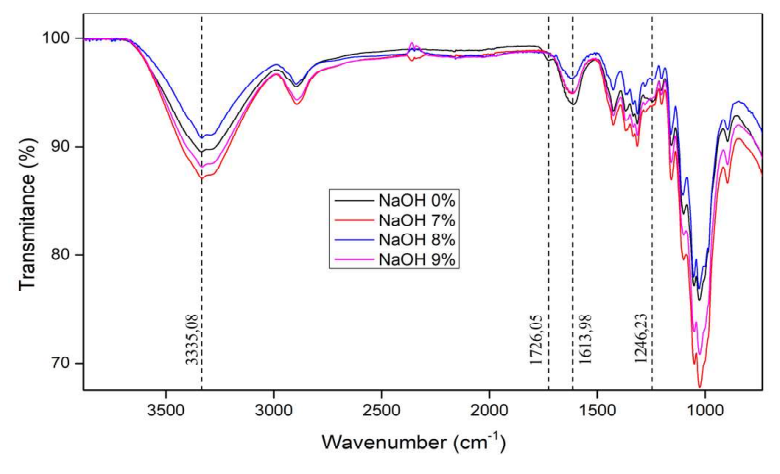

Figure 1. The FT-IR spectrum of ramie fibers resulted from alkaline treatment at $0 \%$ of $\mathrm{NaOH}$ (black color), $7 \%$ of $\mathrm{NaOH}$ (red color), $8 \%$ of $\mathrm{NaOH}$ (blue color) and $9 \%$ of $\mathrm{NaOH}$ (pink color).

passed, thus indicating the fewer compounds contained in the fiber. The function groups observed in this study include hydroxyl $(-\mathrm{OH})$ groups in cellulose, hemicellulose, and lignin indicated at wavenumbers $3335.08 \mathrm{~cm}^{-1}$, a carboxyl function group $(\mathrm{C}=\mathrm{O})$ indicating the presence of hemicellulose at wave number 1726.05 $\mathrm{cm}^{-1}$, the $\mathrm{C}=\mathrm{C}$ function group indicating the presence of lignin at wavenumber $1613.98 \mathrm{~cm}^{-1}$ [14], and the alkane function group (cellulose, hemicellulose, and lignin) at wavenumbers $1246.23 \mathrm{~cm}^{-1}$ [17].

From the analysis of the FT-IR spectrum in Figure 1 , it is known that there is a shift in the peak of the FT-IR spectrum wave that indicates a change in the number of functional groups in ramie fiber after being given alkaline treatment. The hydroxyl functional group $(-\mathrm{OH})$ produced by alkalized ramie fibers using $8 \%$ of $\mathrm{NaOH}$ showed higher spectral peaks than others, indicated at wavenumbers $3335.08 \mathrm{~cm}^{-1}$. This suggests that the resulting ramie fiber has the lowest hydrophilic properties. Thus, it can reduce the ability of composite materials to absorb water. This is following the research results of Refiadi et al. [18], in which the water absorption of bagasse fiber-reinforced epoxy biocomposite was higher when the fiber was not treated with alkalization compared to the alkalization treatment.

Figure 1, also show that the presence of hemicellulose in ramie fiber can be eliminated in the presence of alkaline treatment, indicated by the loss of peaks in the carboxyl function group $(\mathrm{C}=\mathrm{O})$ at wavenumbers of $1726.05 \mathrm{~cm}^{-1}$ after ramie fiber is given alkaline treatment using $7 \%, 8 \%$ and $9 \%$ of $\mathrm{NaOH}$. It is also indicated by the alkane function group at wavenumbers of $1246.23 \mathrm{~cm}^{-1}$. In the image, it is also known that the lignin in the fiber can be removed with the alkalization treatment, the highest peak was indicated by the alkalized ramie fiber using $8 \%$ of $\mathrm{NaOH}$, indicated 
at wave numbers $1613.98 \mathrm{~cm}^{-1}$. From the results of this FT-IR test, it can be concluded that the alkalization method using $8 \%$ of $\mathrm{NaOH}$ provide optimum results in reducing hydroxyl groups in ramie fibers, eliminating hemicellulose components which can reduce the hydrophilic properties of ramie fibers and reduce lignin components that not needed.

\section{PLA/ramie Fiber Composite Tensile Properties}

The composite tensile properties of PLA/ramie fibers in this study were obtained from the results of tensile testing. This test aims to determine the ability of ramie fiber in forming adhesion bonds with the PLA matrix or to know the compatibility between ramie fiber and PLA matrix. The results of the tensile test are shown as shown in Figure 2.

Figure 2 above shows the influence of variations in $\mathrm{NaOH}$ concentration on tensile strength and tensile modulus of PLA/ramie composite material. Based on these images it is known that alkaline ramie fiber can increase the tensile strength of PLA/ramie composites. At $0 \%$ concentration of $\mathrm{NaOH}$ obtained tensile strength of $39.25 \mathrm{MPa}$, and the value of tensile strength PLA/ ramie increased by applying the concentration of $\mathrm{NaOH}$ up to $8 \%$ which is $57.37 \mathrm{MPa}$, and decreased at the concentration of $\mathrm{NaOH}$ at $9 \%$. This increase in tensile

(a)

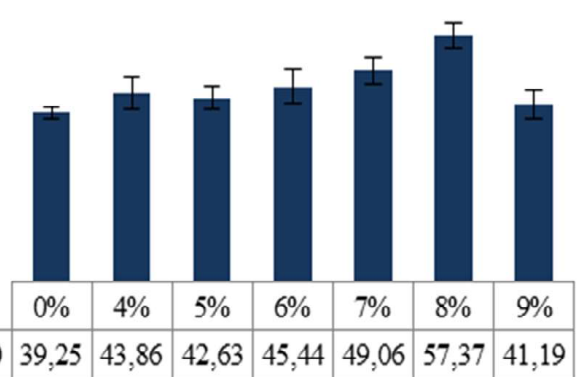

(b)

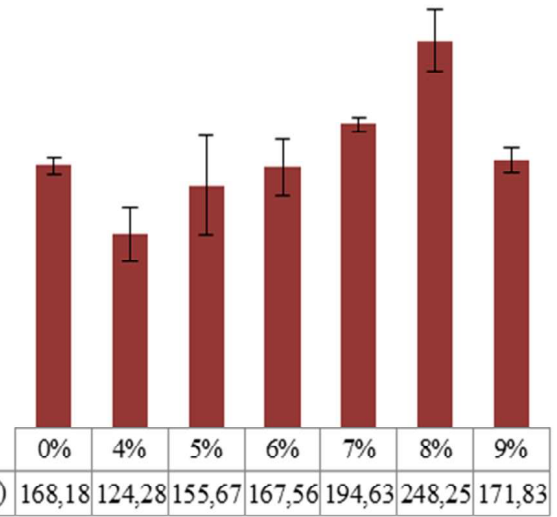

Figure 2. Effects of variations in $\mathrm{NaOH}$ concentration on (a) tensile strength and (b) tensile modulus of PLA/ ramie composite material. strength value is influenced by the properties of ramie fiber, where the alkalization process can produce better ramie fiber properties with a certain $\mathrm{NaOH}$ concentration. This is indicated by an increase in cellulose level in alkaline ramie fiber and a decrease in hydrophilic properties in fiber. Cellulose levels in ramie fiber have a major effect on the mechanical strength of these fibers and hydrophilic properties affect the formation of adhesion bonds between fiber and matrix. From the results of the study, there is a comparable relationship between the cellulose content of ramie fiber and the mechanical strength of the ramie fiber, where increased cellulose level in fiber can increase the tensile strength of the PLA/ramie composites. The highest PLA/ramie composite tensile strength is produced when ramie fiber is catalyzed at an $8 \%$ concentration of $\mathrm{NaOH}$ which is $57.37 \mathrm{MPa}$, while also producing a high cellulose content of $88.180 \%$. The value of the tensile strength is higher when compared to the results of the study by Wardani et al. [19], which produces a maximum tensile strength of 34.3 MPa when the material is synthesized using LDPE (Low Density Poly Ethylene) pineapple leaf fiber reinforced with xylanase enzyme treatment.

In line with the tensile strength value, the highest PLA/ramie tensile modulus value is also obtained at an $8 \%$ concentration of $\mathrm{NaOH}$ which is $248.25 \mathrm{MPa}$. The relationship between tensile strength and PLA/ramie tensile modulus is comparable, except at $0 \%$ concentration of $\mathrm{NaOH}$ or when the ramie fiber is not given an alkaline treatment, resulting in rigid fiber, so the value of the tensile modulus is considerable. However, the value is much smaller compared to the tensile modulus value when ramie fiber is given an alkaline treatment at an $8 \%$ concentration of $\mathrm{NaOH}$. This is due to the better properties of ramie fiber is produced through the chemical treatment of alkaline at $8 \%$ concentration of $\mathrm{NaOH}$ compared to alkalization at $0 \%$ of $\mathrm{NaOH}$, which can result in greater adhesion between the fiber and matrix. According to Debeli et al. [20], in the process of alkaline modification of the fiber surface, sodium hydroxide $(\mathrm{NaOH})$ can remove a collection of impurities from the fiber surface and at the same time produce hydrogen interaction bonds on the fiber surface so that it can bind with a matrix, thus forming a large interfacial force. However, when $\mathrm{NaOH}$ is used too much, it can damage the structure of fiber and result in the decrease of mechanical properties in the fiber, so it is necessary to know the exact concentration to obtain the optimum result. Increased tensile strength and tensile modulus are due to good compatibility between ramie 
fiber and PLA matrix so that the transfer of stress from fiber in the matrix occurs well. Thus, modification of the fiber surface using the alkaline method can be one of the most effective and efficient options in improving the properties of fiber as a reinforcement, which can produce better composite mechanical properties.

\section{Morphology of Ramie Fiber Surface}

The morphology of ramie fiber surface in this study was observed using an electron microscope brand Metkon IMM 902. Observations were made using ramie fiber without alkalization treatment and with alkaline treatment at $8 \%$ and $9 \%$ concentrations of $\mathrm{NaOH}$, which aims to determine the surface structure and diameter. The results of these observations are shown in Figure 3.
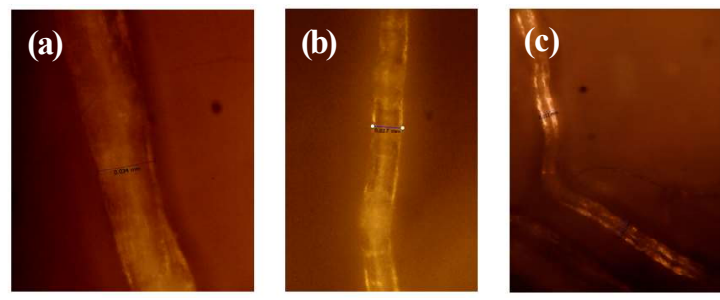

Figure 3. The difference in surface morphology of ramie fiber at various concentrations of $\mathrm{NaOH}$ (a) $0 \%$, (b) $8 \%$, and (c) $9 \%$ at 50x magnification.

Figure 3, is the result of morphological observations of ramie fiber without alkaline treatment or at $0 \%$ concentration of $\mathrm{NaOH}$ and when given alkaline treatment at $8 \%$ and $9 \%$ concentrations of $\mathrm{NaOH}$. The alkaline treatment affects the morphology of the surface of ramie fiber. It makes the fiber cleaner and has a smaller diameter. After alkaline treatment, the fiber surface becomes cleaner which indicates that the impurities are lost during the alkaline chemical treatment [21]. The smaller fiber diameter can produce a larger interfacial area of the fiber, so the resulting fiber adhesion and matrix are also large. The results of these morphological observations are following the results of fiber chemical composition tests and tensile tests that have been conducted before, it shows that alkaline chemical treatment can improve fiber properties both in chemical composition and mechanical properties. The results of morphological observations of ramie fiber from alkaline treatment at $8 \%$ concentration of $\mathrm{NaOH}$ showed good results with the presence of lost impurities and smaller diameter compared to fiber without alkaline treatment, as well as a better structure than the fiber of alkalization result at 9\% concentration of $\mathrm{NaOH}$. The decrease in the diameter of the smaller fibers can produce a compact structure and a more homogeneous surface on the composite material [22].

\section{CONCLUSION}

This study aims to improve the properties of ramie fiber as a composite material reinforced through the alkaline method. Alkaline method using variations of $\mathrm{NaOH}$ concentrations to best understand the exact concentration of $\mathrm{NaOH}$ in producing the best properties of ramie fiber. Based on the results obtained, it can be concluded that the overall properties of ramie fibers have increased with the alkaline treatment with a concentration of $\mathrm{NaOH}$ up to $8 \%$. Alkaline results using $\mathrm{NaOH}$ concentration of $8 \%$ showed the best ramie fiber properties capable of producing high cellulose level of $88.180 \%$, low lignin and hemicellulose level of $2.444 \%$ and $1.446 \%$ respectively, low hydrophilic properties of ramie fiber, clean ramie fiber surface, small diameter, and good fiber structure, resulting in the highest tensile strength and modulus tensile of PLA/ramie composite materials of $57.37 \mathrm{MPa}$ and $248.25 \mathrm{MPa}$, respectively. Thus, the optimum ramie fiber properties are enhanced using alkaline methods at a concentration of $\mathrm{NaOH} 8 \%$.

\section{ACKNOWLEDGMENT}

Researchers would like to thank the University of Jember, especially the Faculty of Physics Department Mathematics and Science, as well as the Physics material laboratory. Thanks also to the supervisor Sujito, Ph.D. for guidance, advice, and input.

\section{REFERENCES}

[1]. P. Sahu and M. K. Gupta. "A review on the properties of natural fibres and its bio-composites: effect of alkali treatment." in Proceedings of the Institution of Mechanical Engineers, Part L: Journal of Materials: Design and Applications, vol. 234, no. 1, pp. 198-217, Sep. 2020.

[2]. A. L. Naidu and P. S. V. R. Rao. "A review on chemical behaviour of natural fiber composites." International Journal of Chemical Sciences, vol. 14, no. 4, pp. 2223-2238, 2016.

[3]. S. Debnath. "Sustainable production of bast fibres." in Proceedings of Sustainable Fibres and Textiles, pp. 69-85, 2017.

[4]. S. Jose, S. Rajna, and P. Ghosh. "Review article ramie fibre processing and value addition." Asian 
Journal of Pharmaceutics, vol. 7, no. 1, pp. 1-9, 2017.

[5]. T. R. Teja, D. V. Rao, A. L. Naidu, and M. V. A. R. Bahubalendruni. "Mechanical and chemical properties of ramie reinforced composites and manufacturing techniques: a review." International Journal of Renewable Energy Development, vol. 8, no. 5, pp. 2349-3585, 2017.

[6]. M. J. Mochane et al.. "Recent progress on natural fiber hybrid composites for advanced applications: a review." Express Polymer Letters, vol. 13, no. 2, pp. 159-198, 2019.

[7]. M. Akay, An Introduction to Polymer Matrix Composites. Irlandia: Ventus Publishing APs, 2015.

[8]. M. G. Raucci et al.. "Effect of citric acid crosslinking cellulose-based hydrogels on osteogenic differentiation." Journal of Biomedical Materials Research - Part A, vol. 103, no. 6, pp. 2045-2056, 2015.

[9]. Y. Kondo and M. Arsyad. "Efek perendaman alkali terhadap kandungan lignoselulosa serat sabut kelapa." in Seminar Nasional Hasil Penelitian \& Pengabdian Kepada Masyarakat (SNP2M), pp. 40-44, 2018.

[10]. D. Jones, G. O. Ormondroyd, and S. F. Curling. "Chemical compositions of natural fibres." Adv. High Strength Nat. Fibre Compos. Constr., pp. 23-58, 2017.

[11]. V. Mittal, Surface Modification of Nanoparticle and Natural Fiber Fillers. Jerman: Wiley-VCH, 2015.

[12]. D. K. Debeli, Z. Qin, and J. Guo. "Study on the pretreatment, physical and chemical properties of ramie fibers reinforced poly (lactic acid)(pla) biocomposite." Journal of Natural Fibers, vol. 15, no. 4, pp. 596-610, 2017.

[13]. E. Syafri, A. Kasim, H. Abral, and A. Asben. "Pengaruh chemical treatment terhadap sifat fisik, kandungan selulosa and kekuatan tarik serat alam rami." Jurnal Teknologi Pertanian Andalas, vol. 19, no. 18-24, 2015.
[14]. K. Kusmono, M. W. Wiland, and M. N. Ilman. "A preliminary study of extraction and characterization of nanocrystalline cellulose (ncc) from ramie fiber." Journal of Material Processing and Characterization. 1(2019), vol. 1, pp. 42-46, 2019.

[15]. N. Hilal, A. F. Ismail, T. Matsuura, and D. OatleyRadcliffe, Membrane Characterization. Netherland: Elsevier B.V, 2017.

[16]. M. Teli and A. Jadhav. "Effect of mercerization on the properties of panandus odorifer lignocellulosic fibre." iosr journal of polymer and textile engineering, vol. 04, no. 01, pp. 07-15, 2017.

[17]. M. K. Bin Bakri, E. Jayamani, S. Hamand, M. R. Rahman, K. H. Soon, and A. Kakar. "Fundamental study on the effect of alkaline treatment on natural fibers structures and behaviors." ARPN Journal of Engineering and Applied Sciences, vol. 11, no. 14,pp. 8759-8763, 2016.

[18]. G. Refiadi, Y. S. Syamsiar, and H. Judawisastra. "Serat bambu pada akibat penyerapan air." Jurnal Sains Materi Indonesia, vol. 19, no. 3, pp. 98-104, 2018.

[19]. L. Warandi, N. Noerati, and D. Sugiyana. "Characterization of composite containing ldpe (low density poly ethylene) and modified pineapple leaf fiber." Jurnal Sains Materi Indonesia, 21(4), pp.184-189, Dec. 2020.

[20]. D. K. Debeli, M. Tebyetekerwa, J. Hao, F. Jiao, and J. Guo. "Improved thermal and mechanical performance of ramie fibers reinforced poly (lactic acid) biocomposites via fiber surface modifications and composites thermal annealing." Polymer Composites, vol. 39, pp. E1867-E1879, 2018.

[21]. C. Wang, Z. Ren, S. Li, and X. Yi. "Effect of ramie fabric chemical treatments on the physical properties of thermoset polylactic acid." Aerospace, vol. 5, no. 3, pp. 1-12, 2018.

[22]. E. Syafri, A. Kasim, H. Abral, A. Asben, and Sudirman. "Berbasis filler cellulose micro fibers rami." Jurnal Sains Materi Indonesia, vol. 19, no. 2, pp. 66-71,2018. 